\title{
THE SYSTEM $2 \mathrm{CaO}_{2} \mathrm{SiO}_{2}-\mathrm{K}_{2} \mathrm{O} . \mathrm{CaO} . \mathrm{SiO}_{2}$, AND OTHER PHASE- EQUILIBRIUM STUDIES INVOLVING POTASH
}

\author{
By William C. Taylor
}

\begin{abstract}
This investigation is one of a series of studies undertaken for the purpose of determining the manner in which $\mathrm{K}_{2} \mathrm{O}$ is combined in portland cement clinker. The present research on the phase-equilibrium relations of $2 \mathrm{CaO} . \mathrm{SiO}_{2}$ and $\mathrm{K}_{2} \mathrm{O}$. CaO. $\mathrm{SiO}_{2}$ was made after preliminary examinations had shown that the compound $\mathrm{K}_{2} \mathrm{O} . \mathrm{Al}_{2} \mathrm{O}_{3}$ was unstable in the presence of $3 \mathrm{CaO} . \mathrm{SiO}_{2}$ and $2 \mathrm{CaO} . \mathrm{SiO}_{2}$. The compounds $2 \mathrm{CaO} . \mathrm{SiO}_{2}$ and $\mathrm{K}_{2} \cdot \mathrm{OCaO} . \mathrm{SiO}_{2}$ were found to form a binary system containing one additional compound having a probable composition of $\mathrm{K}_{2} \mathrm{O}$. $23 \mathrm{CaO} .12 \mathrm{SiO}_{2}$. Thermal, optical, and X-ray diffraction data are presented and a temperature concentration diagram has been constructed. The stability of the compound $\mathrm{K}_{2} \mathrm{O} .23 \mathrm{CaO} .12 \mathrm{SiO}_{2}$ in portland cement clinker prepared only from $\mathrm{K}_{2} \mathrm{O}, \mathrm{CaO}, \mathrm{Al}_{2} \mathrm{O}_{3}, \mathrm{SiO}_{2}$, and $\mathrm{Fe}_{2} \mathrm{O}_{3}$ has been indicated. While no evidence of any other compound of potash in such preparations, heated and cooled under equilibrium conditions, has been obtained, it has been indicated, in the continuation of this series of investigations, that $\mathrm{SO}_{3}$ present in a mixture combines with $\mathrm{K}_{2} \mathrm{O}$ to form $\mathrm{K}_{2} \mathrm{SO}_{4}$. This compound has since been observed in many commercial clinkers.
\end{abstract}

\section{CONTENTS}

I. Introduction

II. Experimental method _.

III. Phase equilibria_........ 313

1. The system $2 \mathrm{CaO} \cdot \mathrm{SiO}_{2}-\mathrm{K}_{2} \mathrm{O} \cdot \mathrm{CaO} \cdot \mathrm{SiO}_{2}$

IV. State of combination of $\mathrm{K}_{2} \mathrm{O}$ in portland cement clinker _...

1. Reactions of $\mathrm{K}_{2} \mathrm{O}$ in mixtures containing compounds present in portland cement clinker.

2. Relations of $3 \mathrm{CaO} . \mathrm{SiO}_{2}$ and $\mathrm{K}_{2} \mathrm{O} \cdot \mathrm{Al}_{2} \mathrm{O}_{3}$

3. Relations of $2 \mathrm{CaO} \cdot \mathrm{SlO}_{2}$ and $\mathrm{K}_{2} \mathrm{O} \cdot \mathrm{Al}_{2} \mathrm{O}_{3} \ldots$

4. Relations of $3 \mathrm{CaO} . \mathrm{SiO}_{2}, 2 \mathrm{CaO} . \mathrm{SiO}_{2}$, and $\mathrm{K}_{2} \mathrm{O} . \mathrm{Al}_{2} \mathrm{O}_{3} \ldots$

5. Relations of $3 \mathrm{CaO} . \mathrm{SiO}_{2}, 2 \mathrm{CaO} . \mathrm{SiO}_{2}, \mathrm{~K}_{2} \mathrm{O} . \mathrm{Al}_{2} \mathrm{O}_{3}$, and $\mathrm{Fe}_{2} \mathrm{O}_{3} \ldots 319$

V. Summary _...

VI. References_.

\section{INTRODUCTION}

A prominent part of the program of the Portland Cement Association Fellowship at the National Bureau of Standards has, for several years, been devoted to the purpose of establishing the constitution of portland cement clinker. Numerous other workers also have contributed largely to the present general conception of the constitution, which is fairly definite with reference to the principal oxides, namely, 
$\mathrm{CaO}, \mathrm{MgO}, \mathrm{SiO}_{2}, \mathrm{Al}_{2} \mathrm{O}_{3}$, and $\mathrm{Fe}_{2} \mathrm{O}_{3}$. In order to make this concept more definite, it is necessary to have knowledge not only of the phase equilibrium relations among the principal oxides but also those of $\mathrm{K}_{2} \mathrm{O}, \mathrm{Na}_{2} \mathrm{O}, \mathrm{SO}_{3}$, and other minor oxides.

The complications usually attending the study of multiple-component systems may be reduced in investigations of the effects of the minor oxides on clinker constitution as follows: First, by conducting a series of investigations on binary and ternary systems in which one of the minor oxides and one or more of the major oxides appear; second, by examining the products of reactions involving one of the minor oxides and one or more of the established clinker compounds. Potash was the minor oxide used in the series of studies reported in the present paper.

Brownmiller [1] ${ }^{1}$ found that $\mathrm{K}_{2} \mathrm{O} \cdot \mathrm{Al}_{2} \mathrm{O}_{3}$ is the only compound of potash which is stable at the liquidus, in the portion of the $\mathrm{K}_{2} \mathrm{O}-\mathrm{CaO}$ $\mathrm{Al}_{2} \mathrm{O}_{3}$ system which he studied. The present author [2] showed that the compound $\mathrm{K}_{2} \mathrm{O} \cdot \mathrm{Al}_{2} \mathrm{O}_{3}$ is stable in the presence of $4 \mathrm{CaO} \cdot \mathrm{Al}_{2} \mathrm{O}_{3} \cdot \mathrm{Fe}_{2} \mathrm{O}_{3}$ and, furthermore, that $\mathrm{K}_{2} \mathrm{O} \cdot \mathrm{Al}_{2} \mathrm{O}_{3}$ can exist in the presence of $2 \mathrm{CaO}$. $\mathrm{Fe}_{2} \mathrm{O}_{3}$, which may be present in clinkers having an $\mathrm{Al}_{2} \mathrm{O}_{3}: \mathrm{Fe}_{2} \mathrm{O}_{3}$ ratio less than 0.64. Obviously the stability or instability of $\mathrm{K}_{2} \mathrm{O} \cdot \mathrm{Al}_{2} \mathrm{O}_{3}$ in the presence of other cement compounds, such as $2 \mathrm{CaO} \cdot \mathrm{SiO}_{2}$ and $3 \mathrm{CaO} \cdot \mathrm{SiO}_{2}$, must be determined; and if new potash compounds should be formed, their phase-equilibrium relations to the various clinker constituents must also be investigated.

The choice of the system $2 \mathrm{CaO} \cdot \mathrm{SiO}_{2}-\mathrm{K}_{2} \mathrm{O} \cdot \mathrm{CaO} . \mathrm{SiO}_{2}$ for investigation was made after preliminary work indicated that $\mathrm{K}_{2} \mathrm{O} \cdot \mathrm{Al}_{2} \mathrm{O}_{3}$ reacts with $2 \mathrm{CaO} . \mathrm{SiO}_{2}$ and $3 \mathrm{CaO} . \mathrm{SiO}_{2}$ to form an unidentified potash-lime-silica compound and that $\mathrm{K}_{2} \mathrm{O} . \mathrm{Al}_{2} \mathrm{O}_{3}$ and $2 \mathrm{CaO} . \mathrm{SiO}_{2}$ do not form a binary system. Mixtures along the join $2 \mathrm{CaO} . \mathrm{SiO}_{2}-\mathrm{K}_{2} \mathrm{O} \cdot \mathrm{CaO} \cdot \mathrm{SiO}_{2}$ in the system $\mathrm{K}_{2} \mathrm{O}-\mathrm{CaO}-\mathrm{SiO}_{2}$ are just beyond that portion of the system investigated by Morey, Kracek, and Bowen [3]. These investigators report that the primary phase $2 \mathrm{CaO} \cdot \mathrm{SiO}_{2}$ appears in the field adjacent to that of $\mathrm{K}_{2} \mathrm{O} . \mathrm{CaO}$. $\mathrm{SiO}_{2}$ and that "there is some indication that the index of $2 \mathrm{CaO} \mathrm{SiO}_{2}$ in this region is lowered slightly by solid solution, but this is not certain." Thus the possibility remains that some compound exists which is similar to $2 \mathrm{CaO} . \mathrm{SiO}_{2}$ in appearance but between $2 \mathrm{CaO} . \mathrm{SiO}_{2}$ and $\mathrm{K}_{2} \mathrm{O} \cdot \mathrm{CaO} \cdot \mathrm{SiO}_{2}$ in composition. In preliminary experiments by the author, free $\mathrm{CaO}$ was always found by microscopical examination in heated charges when mixtures of $\mathrm{CaO}$ and $\mathrm{SiO}_{2}$ in molar ratios greater than 2:1, respectively, had been added to $\mathrm{K}_{2} \mathrm{O} . \mathrm{CaO} . \mathrm{SiO}_{2}$.

\section{EXPERIMENTAL METHOD}

For the study of the system $2 \mathrm{CaO} \cdot \mathrm{SiO}_{2}-\mathrm{K}_{2} \mathrm{O} \cdot \mathrm{CaO} \cdot \mathrm{SiO}_{2}$, and for the preliminary experiments reported in part in this paper, the following compounds were prepared: $2 \mathrm{CaO}_{\mathrm{SiO}}$ (largely in the gamma form), $3 \mathrm{CaO} . \mathrm{SiO}_{2}, \mathrm{~K}_{2} \mathrm{O} . \mathrm{CaO} \cdot \mathrm{SiO}_{2}, \mathrm{~K}_{2} \mathrm{O} \cdot \mathrm{Al}_{2} \mathrm{O}_{3}, 3 \mathrm{CaO} \cdot \mathrm{Al}_{2} \mathrm{O}_{3}$, and $4 \mathrm{CaO} \cdot \mathrm{Al}_{2} \mathrm{O}_{3}$. $\mathrm{Fe}_{2} \mathrm{O}_{3}$. The exact compositions were determined by chemical analyses and microscopical examinations. Various mixtures of these compounds were intimately ground in an agate mortar and then heated in open platinum boats in an electric furnace at about $1,250^{\circ} \mathrm{C}$ for

1 Figures in brackets indicate the literature references at the end of this paper. 
$3 / 2$ hour. Losses of potash by volatilization from these preparations were determined by weight differences before and after heating, and compensating additions of $\mathrm{K}_{2} \mathrm{O}$ were made. The heated preparations were reground and placed in sealed bottles, which were shaken to insure a high degree of homogeneity. Small charges for thermal study were taken from these base samples, the general procedure, previously outlined $[1,2]$, being followed.

Charges were examined microscopically by two different methodspowder specimens viewed by transmitted light, and polished thin sections which were viewed by both transmitted and reflected light.

\section{PHASE EQUILIBRIA}

\section{THE SYSTEM $2 \mathrm{CaO} . \mathrm{SiO}_{2}-\mathrm{K}_{2} \mathrm{O} \cdot \mathrm{CaO} \cdot \mathrm{SiO}_{2}$}

Mixtures of $2 \mathrm{CaO} . \mathrm{SiO}_{2}$ and $\mathrm{K}_{2} \mathrm{O} \cdot \mathrm{CaO} \cdot \mathrm{SiO}_{2}$ throughout the entire range were studied. The compound $\mathrm{K}_{2} \mathrm{O} \cdot \mathrm{CaO} \cdot \mathrm{SiO}_{2}$ persisted in the completely crystallized charges until the $2 \mathrm{CaO} \cdot \mathrm{SiO}_{2}: \mathrm{K}_{2} \mathrm{O} \cdot \mathrm{CaO} \cdot \mathrm{SiO}_{2}$ ratio of 9:1 was reached. In this charge only one phase, with the exception of about 0.5 percent of extraneous material, existed. The amounts of this phase had been increasing with increasing ratios of $2 \mathrm{CaO} . \mathrm{SiO}_{2}$ to $\mathrm{K}_{2} \mathrm{O} \cdot \mathrm{CaO} \cdot \mathrm{SiO}_{2}$ in this series of changes. The ratio of $9: 1$ by weight, corresponding to a molar ratio of $11: 1$, indicated that 11 molecules of $2 \mathrm{CaO} . \mathrm{SiO}_{2}$ combined with 1 molecule of $\mathrm{K}_{2} \mathrm{O} . \mathrm{CaO} \cdot \mathrm{SiO}_{2}$ to form a new compound $\mathrm{K}_{2} \mathrm{O} .23 \mathrm{CaO} .12 \mathrm{SiO}_{2}$ containing 4.48 percent of $\mathrm{K}_{2} \mathrm{O}, 61.28$ percent of $\mathrm{CaO}$, and 34.25 percent of $\mathrm{SiO}_{2}$. The X-ray diffraction pattern ${ }^{2}$ obtained from this charge, while not very sharp, differed distinctly from the pattern of $\beta-2 \mathrm{CaO} \cdot \mathrm{SiO}_{2}$ and $\mathrm{K}_{2} \mathrm{O} \cdot \mathrm{CaO} \cdot \mathrm{SiO}_{2}$. Although the evidence points to the probable existence of the compound $\mathrm{K}_{2} \mathrm{O} .23 \mathrm{CaO} .12 \mathrm{SiO}_{2}$, it is recognized that points on a liquidus curve near $\mathrm{K}_{2} \mathrm{O} .23 \mathrm{CaO} .12 \mathrm{SiO}_{2}$ would be necessary to establish the composition. The possibility of limited solid solution of $2 \mathrm{CaO} . \mathrm{SiO}_{2}$ and $\mathrm{K}_{2}$ O.CaO. $\mathrm{SiO}_{2}$ with a compound having a composition slightly different from $\mathrm{K}_{2} \mathrm{O} .23 \mathrm{CaO} .12 \mathrm{SiO}_{2}$ remains. The temperatures which would be required for the location of the liquidus curve in this portion of the system are far beyond the limits of the furnace employed.

McMurdie [4], working independently, also came to the conclusion that a ternary compound having the composition $\mathrm{K}_{2} \mathrm{O} .23 \mathrm{CaO} .12 \mathrm{SiO}_{2}$ probably exists in the $\mathrm{K}_{2} \mathrm{O}-\mathrm{CaO}-\mathrm{SiO}_{2}$ system.

The thermal data for the system are given in table 1 . It will be seen from the table that no glass was found in any of the quenched samples containing more than 90 percent of $2 \mathrm{CaO} . \mathrm{SiO}_{2}$ and that the charges apparently were composed of only one phase in each case. The refractive indices of these charges increased as the ratio of $2 \mathrm{CaO} . \mathrm{SiO}_{2}: \mathrm{K}_{2} \mathrm{O} . \mathrm{CaO} . \mathrm{SiO}_{2}$ increased, and it became increasingly difficult to distinguish the material from $\beta-2 \mathrm{CaO} . \mathrm{SiO}_{2}$. Polysynthetic twinning, characteristic of $\beta-2 \mathrm{CaO} . \mathrm{SiO}_{2}$ which had at some time been in the $\alpha$ state, was common. These results indicated the possibility that the compound $\mathrm{K}_{2} \mathrm{O} .23 \mathrm{CaO} .12 \mathrm{SiO}_{2}$ passed into solid solution with $\beta-2 \mathrm{CaO} . \mathrm{SiO}_{2}$ in all proportions. The X-ray diffraction pattern obtained from the charge composed of 91.4 percent of $\beta-2 \mathrm{CaO} . \mathrm{SiO}_{2}$ and 8.6 percent of $\mathrm{K}_{2} \mathrm{O} .23 \mathrm{CaO} .12 \mathrm{SiO}_{2}$, however, showed the lines characteristic of $\beta-2 \mathrm{CaO} . \mathrm{SiO}_{2}$ as well as those characteristic

3 All X-ray photographs referred to in this paper were made by H. F, McMurdie. 
of $\mathrm{K}_{2} \mathrm{O} .23 \mathrm{CaO} \cdot 12 \mathrm{SiO}_{2}$. The lines of the latter compound were considerably weaker than those in the X-ray photograph of the charge composed of 90 percent of $2 \mathrm{CaO} \cdot \mathrm{SiO}_{2}$ and 10 percent of $\mathrm{K}_{2} \mathrm{O} \cdot \mathrm{CaO} \cdot \mathrm{SiO}_{2}$. Since the X-ray data ruled out the possibility of continuous solid solution, it was assumed that intimate crystallization of the two compounds had occurred, and because of the similarity in optical properties, the product appeared as one phase. This was all the more likely since no liquid was formed in any case from which one of the phases could crystallize. The complexity of the twinning also was a factor in rendering identification more difficult.

TABLE 1. - Thermal data relative to the system $2 \mathrm{CaO} . \mathrm{SiO}_{2}-\mathrm{K}_{2} \mathrm{O} \cdot \mathrm{CaO} \cdot \mathrm{SiO}_{2}$

Note: In this and in subsequent tables the following abbreviations apply:

$\left.\begin{array}{ll}\mathrm{C}_{2} \mathrm{~S} & \text { for } 2 \mathrm{CaO}_{2} \mathrm{SiO}_{2} \\ \mathrm{KCS}_{\mathrm{K}} & \text { for } \mathrm{K}_{2} \mathrm{O} . \mathrm{CaO} . \mathrm{SiO}_{2}-\cdot- \\ \mathrm{KC}_{23} \mathrm{~S}_{12} & \text { for } \mathrm{K}_{2} \mathrm{O} .23 \mathrm{CaO} .12 \mathrm{SiO}_{2}\end{array}\right\}$ Tables 1 and 4

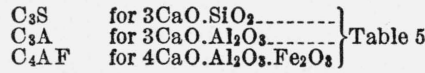

\begin{tabular}{|c|c|c|c|}
\hline \multicolumn{2}{|c|}{ Composition } & \multirow{2}{*}{$\begin{array}{l}\text { Temperature } \\
\text { of quench }\end{array}$} & \multirow{2}{*}{ Examination } \\
\hline $\mathrm{C}_{2} \mathrm{~S}$ & $\mathrm{KCS}$ & & \\
\hline$\%$ & $\%$ & - $C$ & \\
\hline 0 & 100 & $\begin{array}{l}1,625 \\
1,617 \\
1,627\end{array}$ & $\begin{array}{l}\text { Glass; small amount of crystalline material. } \\
\text { All crystalline. (mp.1, } 630^{\circ} \mathrm{C} \text {, according to Morey, Kracek, and Bowen. } \\
\text { Glass. }\end{array}$ \\
\hline 5 & 95 & 1,619 & $\begin{array}{l}\mathrm{KCS} ; \text { glass. } \\
\mathrm{KCS}: \mathrm{KC}_{23} \mathrm{~S}_{13} ; \text { trace of glass. }\end{array}$ \\
\hline 8 & 92 & $\begin{array}{l}1,598 \\
1,590 \\
1,650\end{array}$ & $\begin{array}{l}\text { Glass. } \\
\mathrm{KC}_{23} \mathrm{~S}_{12} ; \mathrm{KCS} \text {. } \\
\text { Glass. }\end{array}$ \\
\hline 10 & 90 & $\begin{array}{l}1,637 \\
1,625 \\
1,598 \\
1,670\end{array}$ & $\begin{array}{l}\text { Do. } \\
\text { Small amount of } \mathrm{KC}_{23} \mathrm{~S}_{12} ; \text { glass. } \\
\mathrm{KC}_{23} \mathrm{~S}_{12} ; \mathrm{KCS} \text {; glass. }\end{array}$ \\
\hline 15 & 85 & $\begin{array}{l}1,660 \\
1,600 \\
1,590\end{array}$ & $\begin{array}{l}\text { Small amount of } \mathrm{KC}_{23} \mathrm{~S}_{12} ; \text { much glass. } \\
\mathrm{KC}_{23} \mathrm{~S}_{12} ; \text { glass. } \\
\mathrm{KC}_{23} \mathrm{~S}_{12} ; \mathrm{KCS} \text {. }\end{array}$ \\
\hline 20 & 80 & $\begin{array}{l}1,660 \\
1,598 \\
1,590\end{array}$ & $\begin{array}{l}\mathrm{KC}_{23} \mathrm{~S}_{12} ; \text { glass. } \\
\mathrm{KC}_{23} \mathrm{~S}_{12} ; \mathrm{KCS} ; \text { slight amount of glass. } \\
\mathrm{KC}_{23} \mathrm{~S}_{12} ; \mathrm{KCS} \text {. }\end{array}$ \\
\hline 30 & 70 & $\begin{array}{l}1,650 \\
1,618 \\
1,640\end{array}$ & $\begin{array}{l}\mathrm{K}_{2} \mathrm{C}_{33} \mathrm{~S}_{21} ; \text { glass. } \\
\text { Do. } \\
\text { Do. }\end{array}$ \\
\hline 40 & 60 & $\begin{array}{l}1,612 \\
1,598 \\
1,590 \\
1,640\end{array}$ & $\begin{array}{l}\text { Do. } \\
\mathrm{KC}_{23} \mathrm{~S}_{13} ; \mathrm{KCS} ; \text { slight amount of glass. } \\
\mathrm{KC}_{23} \mathrm{~S}_{12} ; \mathrm{KCS} \text {. } \\
\mathrm{KC}_{23} \mathrm{~S}_{12} ; \text { glass. }\end{array}$ \\
\hline 50 & 50 & $\begin{array}{l}1,600 \\
1,590 \\
1,580 \\
1,660\end{array}$ & $\begin{array}{l}\mathrm{D} \\
\mathrm{Do} . \\
\mathrm{KC}_{23} \mathrm{~S}_{12}, \mathrm{KCS} ; \text { trace of glass. } \\
\mathrm{KC}_{23} \mathrm{~K}_{12} ; \mathrm{KCS} \text {. } \\
\mathrm{KC}_{23} \mathrm{~S}_{12} ; \text { glass. }\end{array}$ \\
\hline 85 & 15 & $\begin{array}{l}1,600 \\
1,590 \\
1,520\end{array}$ & $\begin{array}{l}\mathrm{Do} \text {. } \\
\mathrm{KC}_{23} \mathrm{~S}_{12} ; \mathrm{KCS} \text {. } \\
\mathrm{KC}{ }_{23} \mathrm{~S}_{12} \text { about } 7 \% \text { of KCS. }\end{array}$ \\
\hline 88 & 12 & $\left\{\begin{array}{l}1,660 \\
1,520\end{array}\right.$ & KC ${ }_{23} \mathrm{~S}_{12} ;$ glass. \\
\hline 90 & 10 & $\begin{array}{l}1,650 \\
1,600 \\
1,520\end{array}$ & $\begin{array}{l}\text { Except for trace of glass, one crystalline phase. } \\
\text { One crystalline phase. } \\
\text { Do. }\end{array}$ \\
\hline 91.4 & 8.6 & $\begin{array}{l}1,628 \\
1,520\end{array}$ & $\begin{array}{l}\text { Apparently one crystalline phase. } \\
\text { Do. }\end{array}$ \\
\hline 95 & 5 & $\begin{array}{l}1,628 \\
1,555\end{array}$ & Do. \\
\hline 98 & 2 & 1,628 & Do. \\
\hline 100 & 0 & 1,555 & (mp. $2,130^{\circ} \mathrm{C}$, according to Rankin and Wright). \\
\hline
\end{tabular}


None of the charges which contained more than 15 percent of $2 \mathrm{CaO} . \mathrm{SiO}_{2}$ was melted completely at the temperatures employed (see table 1). Sufficient data were obtained, however, to indicate that $2 \mathrm{CaO} . \mathrm{SiO}_{2}$ and $\mathrm{K}_{2} \mathrm{O} . \mathrm{CaO} . \mathrm{SiO}_{2}$ constitute a binary system containing one intermediate compound having the probable composition $\mathrm{K}_{2} \mathrm{O}$. $23 \mathrm{CaO} \cdot 12 \mathrm{SiO}_{2}$. The composition of the eutectic formed by $\mathrm{K}_{2} \mathrm{O}$. $23 \mathrm{CaO} .12 \mathrm{SiO}_{2}$ and $\mathrm{K}_{2} \mathrm{O} . \mathrm{CaO} . \mathrm{SiO}_{2}$ was 8.9 percent of the former, 91.1 percent of the latter (8.0 percent of $2 \mathrm{CaO} . \mathrm{SiO}_{2}$ and 92.0 percent of $\left.\mathrm{K}_{2} \mathrm{O} . \mathrm{CaO} \cdot \mathrm{SiO}_{2}\right)$. The eutectic melted at $1,598^{\circ} \pm 10^{\circ} \mathrm{C}$. The liquidus temperature of the charge containing 15 percent of $2 \mathrm{CaO}^{-\mathrm{SiO}_{2}}$ and 85 percent of $\mathrm{K}_{2} \mathrm{O} . \mathrm{CaO} \cdot \mathrm{SiO}_{2}$ was $1,670^{\circ} \mathrm{C}$. This temperature

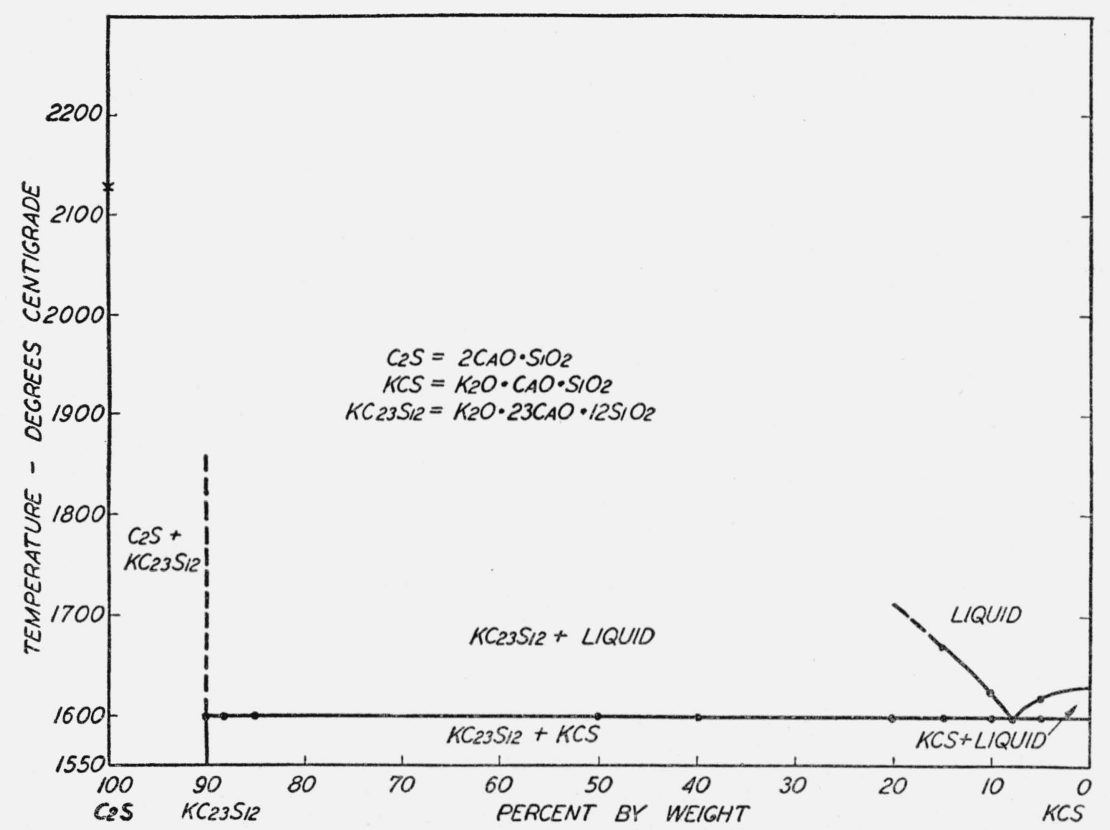

Figure 1.-The system $2 \mathrm{CaO}_{2} \mathrm{SiO}_{2}-\mathrm{K}_{2} \mathrm{O} \cdot \mathrm{CaO} . \mathrm{SiO}_{2}$.

was about the maximum obtainable in the furnace employed; hence the thermal data obtained for the system were incomplete beyond this point. The incomplete temperature-concentration diagram is given in figure 1.

A much larger quantity of the compound $\mathrm{K}_{2} \mathrm{O} .23 \mathrm{CaO} .12 \mathrm{SiO}_{2}$ was prepared in a horizontal electric furnace [5]. In order to overcome the difficulties of adjusting the $\mathrm{K}_{2} \mathrm{O}$ content of the preparation, caused by the increase in volatilization of $\mathrm{K}_{2} \mathrm{O}$ during repeated heat treatments in open platinum boats, the following procedure was adopted, after many preliminary tests. To the powdered $\mathrm{CaCO}_{3}, \mathrm{~K}_{2} \mathrm{O} \cdot \mathrm{SiO}_{2}$ and $\mathrm{SiO}_{2}$, mixed in the proportions $\mathrm{K}_{2} \mathrm{O} .23 \mathrm{CaO} .12 \mathrm{SiO}_{2}$, there was added a weighed quantity of potassium oxalate equal in $\mathrm{K}_{2} \mathrm{O}$ content to that previously introduced as $\mathrm{K}_{2} \mathrm{O} \cdot \mathrm{SiO}_{2}$. Thus the total $\mathrm{K}_{2} \mathrm{O}$ content of the unheated mixture was twice that required. The $\mathrm{K}_{2} \mathrm{O}$ content of the heated preparation was determined directly by chemical analysis, and not by loss of weight. The mixture was subjected 
to a preliminary heat treatment of $1,250^{\circ} \mathrm{C}$ for 8 minutes and then finely ground. Three successive heat treatments at $1,500^{\circ} \mathrm{C}$ for 8 minutes were made with intermediate fine grinding, microscopical examination, and complete chemical analysis. The final product consisted almost entirely of a single crystalline phase, apparently identical with that found in the small heated charge of a 9:1 2CaO. $\mathrm{SiO}_{2}: \mathrm{K}_{2} \mathrm{O}$. $\mathrm{CaO} . \mathrm{SiO}_{2}$ mixture. In addition to this crystalline phase, a microscopical examination showed the presence of small quantities of extraneous materials. They consisted of a few grains of $\mathrm{CaO}$, occasional thin veins of an isotropic material having a low index of refraction, and a number of small specks of an unidentifiable substance.

A comparison of the chemical analysis of the preparation with the theoretical composition of $\mathrm{K}_{2} \mathrm{O} .23 \mathrm{CaO} .12 \mathrm{SiO}_{2}$ is given in table 2 .

TABLE 2.-A comparison of the chemical analysis of a preparation of $\mathrm{K}_{2} \mathrm{O} .23 \mathrm{CaO} .12 \mathrm{SiO}_{2}$ with the theoretical composition

\begin{tabular}{|c|c|c|}
\hline Constituent & Preparation 1 & $\begin{array}{c}\text { Theoretical } \\
\mathrm{K}_{2} \mathrm{O} .23 \mathrm{CaO} .12 \mathrm{SiO}\end{array}$ \\
\hline $\begin{array}{l}\mathrm{CaO} \\
\mathrm{SiO}_{2} \\
\mathrm{~K}_{2} \mathrm{O}_{2} \\
\mathrm{R}_{2} \mathrm{O}_{3} \\
\text { Free } \mathrm{CaO}-\end{array}$ & $\begin{array}{cc}\% & \\
& 61.51 \\
& 33.55 \\
& 4.60 \\
& .38 \\
& .4\end{array}$ & $\begin{array}{rr} & \\
& \\
& 61.28 \\
& 34.25 \\
& 4.48 \\
& \\
& \end{array}$ \\
\hline
\end{tabular}

1 Chemical analysis by E. G. Siggers. Potash was determined by the J. Lawrence Smith procedure.

The amounts of $\mathrm{SiO}_{2}$ and of combined $\mathrm{CaO}$ (61.11 percent) are slightly less than their respective theoretical values, but that of $\mathrm{K}_{2} \mathrm{O}$ is slightly more. The presence of the extraneous material mentioned may have been the result of the slight deficiency of $\mathrm{SiO}_{2}$ and $\mathrm{CaO}$, the excess of $\mathrm{K}_{2} \mathrm{O}$, and the presence of the small amounts of $\mathrm{R}_{2} \mathrm{O}_{3}$.

A microscopical examination of a powdered sample of this preparation showed that $\mathrm{K}_{2} \mathrm{O} .23 \mathrm{CaO} .12 \mathrm{SiO}_{2}$ was present as irregularly shaped, somewhat rounded grains, exhibiting complex polysynthetic twinning similar to that of $\alpha-2 \mathrm{CaO} \cdot \mathrm{SiO}_{2}$ but having lower refractive indices and birefringence than that compound.

A comparison of the optical properties of $\mathrm{K}_{2} \mathrm{O} .23 \mathrm{CaO} .12 \mathrm{SiO}_{2}$ with those of $\alpha$ - and $\beta-2 \mathrm{CaO} . \mathrm{SiO}_{2}$ and of $3 \mathrm{CaO} . \mathrm{SiO}_{2}$ is given in table 3 .

TABLE 3.-Optical properties of $\mathrm{K}_{2} \mathrm{O} .23 \mathrm{CaO} .12 \mathrm{SiO}_{2}, \alpha-$ and $\beta-\mathrm{CaO} . \mathrm{SiO}_{2}$, and $3 \mathrm{CaO} . \mathrm{SiO}_{2}$

\begin{tabular}{|c|c|c|c|c|}
\hline \multirow{2}{*}{ Compound } & \multirow{2}{*}{ Optical character } & \multicolumn{3}{|c|}{ Index of refraction } \\
\hline & & $\alpha$ & $\gamma$ & $\begin{array}{l}\text { Double } \\
\text { refraction }\end{array}$ \\
\hline $\begin{array}{l}\mathrm{K}_{2} \mathrm{O} .23 \mathrm{CaO} .12 \mathrm{SiO}_{2} \\
\alpha-2 \mathrm{CaO} . \mathrm{SiO}_{2} \\
\beta-2 \mathrm{CaO} . \mathrm{SiO}_{2}\end{array}$ & $\begin{array}{l}\text { Uniaxial positive } \\
\text { Biaxial positive.... }\end{array}$ & $\begin{array}{l}1.695 \\
1.715 \\
1.717\end{array}$ & $\begin{array}{l}1.703 \\
1.737 \\
1.735\end{array}$ & $\begin{array}{r}0.008 \\
.022 \\
.018\end{array}$ \\
\hline $3 \mathrm{CaO} \cdot \mathrm{SiO}_{2}$ & ..... do .... & \multicolumn{2}{|c|}{ Mean $=1.715$} & .005 \\
\hline
\end{tabular}




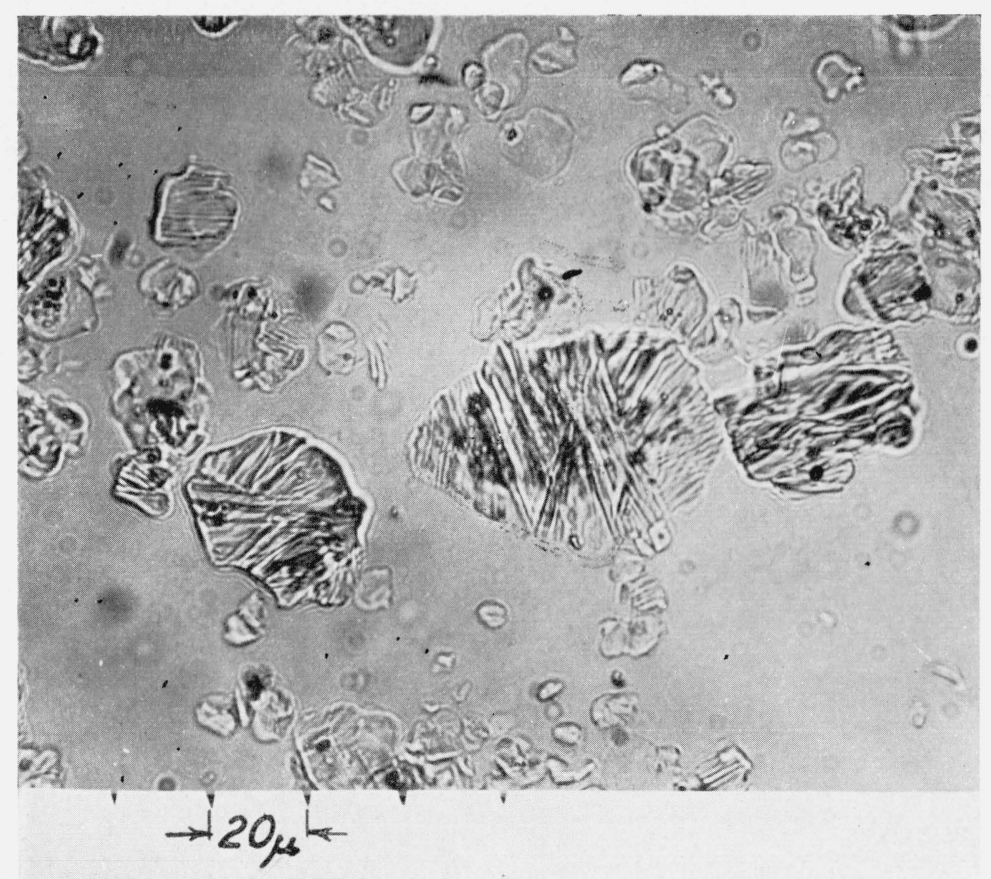

FIGURE 2.-Crystals having the probable formula $\mathrm{K}_{2} \mathrm{O} .23 \mathrm{CaO} .12 \mathrm{SiO}_{2}$. Ordinary transmitted light.

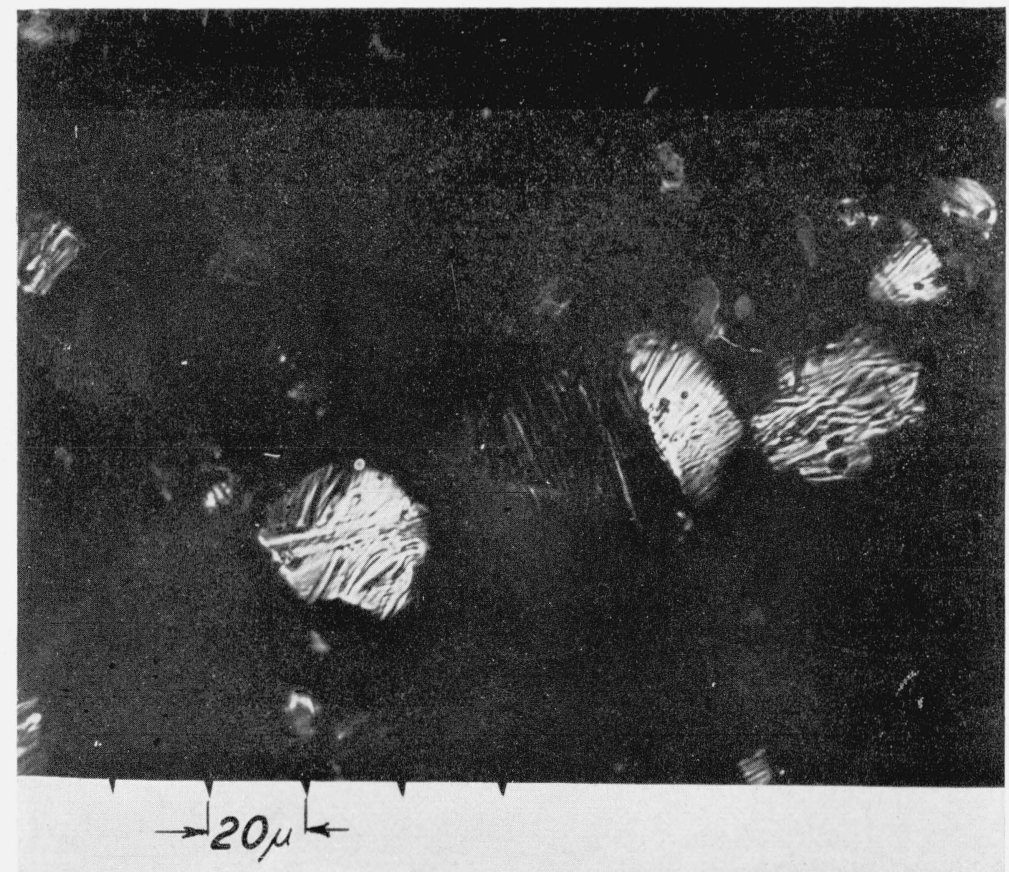

Figure 3.-Crystals having the probable formula $\mathrm{K}_{2} \mathrm{O} .23 \mathrm{CaO} .12 \mathrm{SiO}_{2}$. Same field as figure 2 but between crossed nicols. 
It was not possible to measure accurately the refractive indices of most of the grains of $\mathrm{K}_{2} \mathrm{O} \cdot 23 \mathrm{CaO} .12 \mathrm{SiO}_{2}$ because of the complex twinning, accordingly the values given in the above table were obtained from grains less complexly twinned.

Figure 2 is a photomicrograph of a powder sample of this preparation in transmitted ordinary light. Figure 3 shows the same field between crossed nicols.

A comparison, given in table 4, of the interplanar spacings of the X-ray diffraction pattern obtained from a powdered sample of this preparation, with that of $\beta-2 \mathrm{CaO} . \mathrm{SiO}_{2}$, shows the absence of most of the lines characteristic of $\beta-2 \mathrm{CaO} . \mathrm{SiO}_{2}$, and the presence of 10 lines not found in the pattern of $\beta-2 \mathrm{CaO} \cdot \mathrm{SiO}_{2}$. The differences between the patterns of $3 \mathrm{CaO} . \mathrm{SiO}_{2}$ [6] and $\mathrm{K}_{2} \mathrm{O} .23 \mathrm{CaO} .12 \mathrm{SiO}_{2}$ are even more marked.

TABLE 4.-Interplanar spacings of the diffraction patterns of $\beta-2 \mathrm{CaO}^{-\mathrm{SiO}_{2}}$ and $\mathrm{K}_{2} \mathrm{O} .23 \mathrm{CaO} .12 \mathrm{SiO}_{2}$

[Measured by H. F. McMurdie]

[ $\mathrm{s}=$ strong, $\mathrm{vs}=$ very strong, $\mathrm{m}=$ medium, $\mathrm{w}=$ weak, $\mathrm{vw}=$ very weak, $\mathrm{b}=$ broad.

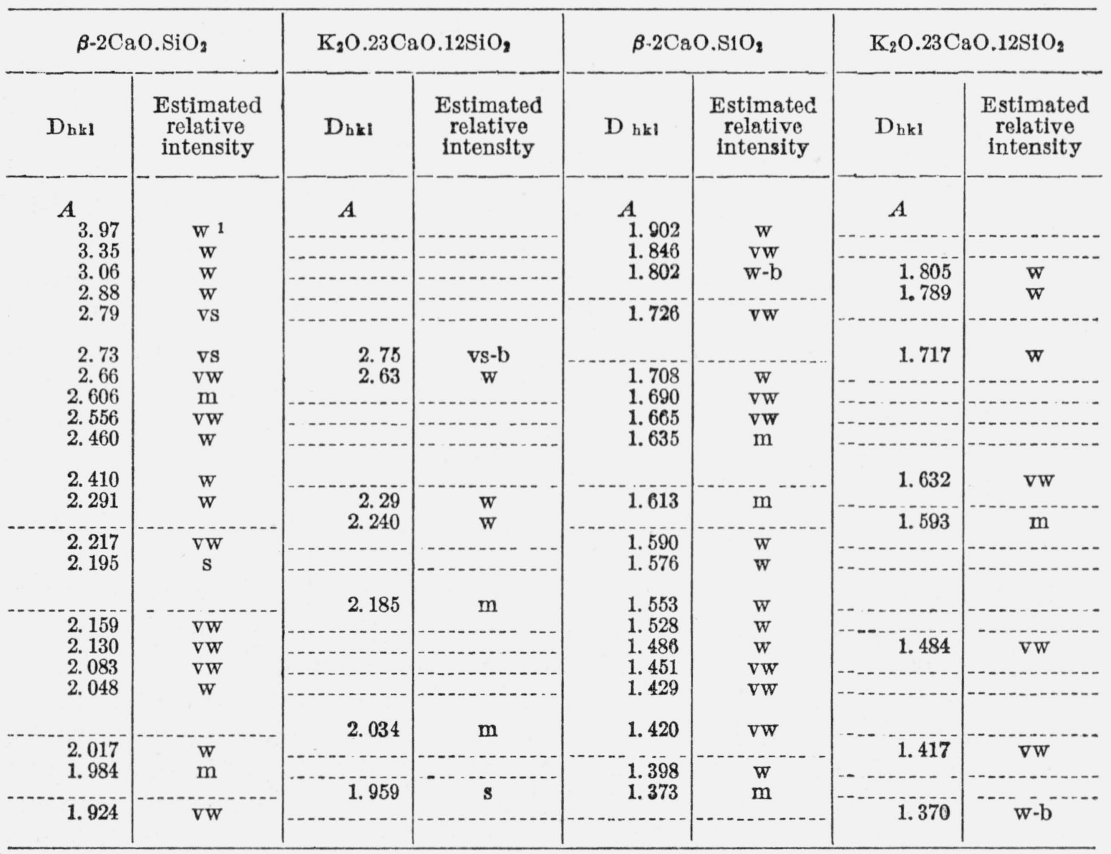

\section{STATE OF COMBINATION OF $\mathrm{K}_{2} \mathrm{O}$ IN PORTLAND CEMENT CLINKER}

\section{REACTIONS OF $\mathrm{K}_{2} \mathrm{O}$ IN MIXTURES CONTAINING COMPOUNDS PRESENT IN PORTLAND CEMENT CLINKER}

As was stated in the introduction to this paper, it has been established that $\mathrm{K}_{2} \mathrm{O} \cdot \mathrm{Al}_{2} \mathrm{O}_{3}$ is the only stable compound of $\mathrm{K}_{2} \mathrm{O}$ in that part of the $\mathrm{K}_{2} \mathrm{O}-\mathrm{CaO}-\mathrm{Al}_{2} \mathrm{O}_{3}$ system which is of interest in the study of portland cement clinker. 
As a further step in the determination of the state of combination of $\mathrm{K}_{2} \mathrm{O}$ in clinker, it is important to discover whether $\mathrm{K}_{2} \mathrm{O} \cdot \mathrm{Al}_{2} \mathrm{O}_{3}$ or some other compound containing $\mathrm{K}_{2} \mathrm{O}$ is stable in that part of the fivecomponent system, $\mathrm{K}_{2} \mathrm{O}-\mathrm{CaO}-\mathrm{Al}_{2} \mathrm{O}_{3}-\mathrm{Fe}_{2} \mathrm{O}_{3}-\mathrm{SiO}_{2}$, related to cement clinker composition.

\section{RELATIONS OF $3 \mathrm{CaO} . \mathrm{SiO}_{2}$ AND $\mathrm{K}_{2} \mathrm{O} \cdot \mathrm{Al}_{2} \mathrm{O}_{3}$}

For the preliminary work on this problem, mixtures within the range of 99 percent of $3 \mathrm{CaO} \cdot \mathrm{SiO}_{2}, 1$ percent of $\mathrm{K}_{2} \mathrm{O} \cdot \mathrm{Al}_{2} \mathrm{O}_{3}$ to 85 percent of $3 \mathrm{CaO} . \mathrm{SiO}_{2}, 15$ percent of $\mathrm{K}_{2} \mathrm{O} . \mathrm{Al}_{2} \mathrm{O}_{3}$ were prepared. Because it was observed that liquid was first formed in the charges at some temperature between $1,400^{\circ}$ and $1,450^{\circ} \mathrm{C}$, the samples were heated at $1,450^{\circ} \mathrm{C}$ for 10 minutes, cooled to $1,400^{\circ} \mathrm{C}$ at the rate of $1 / 2^{\circ} \mathrm{C}$ per minute, and then quenched. The compound $\mathrm{K}_{2} \mathrm{O} \cdot \mathrm{Al}_{2} \mathrm{O}_{3}$, which is formed in the $\mathrm{K}_{2} \mathrm{O}-\mathrm{CaO}-\mathrm{Al}_{2} \mathrm{O}_{3}$ system, was not positively identified in any of the completely crystallized charges in which the molar ratio of $3 \mathrm{CaO} . \mathrm{SiO}_{2}$ to $\mathrm{K}_{2} \mathrm{O} . \mathrm{Al}_{2} \mathrm{O}_{3}$ was greater than $6: 1$ (87.5 percent of $3 \mathrm{CaO}^{-\mathrm{SiO}_{2}}$ and 12.5 percent of $\mathrm{K}_{2} \mathrm{O} \cdot \mathrm{Al}_{2} \mathrm{O}_{3}$ ). Large amounts of a birefringent phase with a mean index of about 1.70 were observed. Tricalcium aluminate and much uncombined $\mathrm{CaO}$ were present also. Tricalcium silicate was identified only in charges resulting from mixtures originally containing 95 percent or more of $3 \mathrm{CaO} \cdot \mathrm{SiO}_{2}$. The amounts were small and probably represented the excess of $3 \mathrm{CaO} . \mathrm{SiO}_{2}$ in the reaction with $\mathrm{K}_{2} \mathrm{O} \cdot \mathrm{Al}_{2} \mathrm{O}_{3}$. In mixtures having the molar ratio $3 \mathrm{CaO} \cdot \mathrm{SiO}_{2}: \mathrm{K}_{2} \mathrm{O} \cdot \mathrm{Al}_{2} \mathrm{O}_{3}$ of $6: 1$ or less, the amounts of the new crystalline phase appeared to be about the same as in mixtures of higher ratios, but some residual $\mathrm{K}_{2} \mathrm{O} \cdot \mathrm{Al}_{2} \mathrm{O}_{3}$ was apparently present in addition to $3 \mathrm{CaO} \cdot \mathrm{Al}_{2} \mathrm{O}_{3}$ and $\mathrm{CaO}$. Assuming that the new crystalline phase which is the product of these reactions has the composition $\mathrm{K}_{2} \mathrm{O} .23 \mathrm{CaO} .12 \mathrm{SiO}_{2}$, the following equation expresses the reaction occurring when the $12: 1$ ratio mixture (93 percent of $3 \mathrm{CaO} . \mathrm{SiO}_{2}$ and 7 percent of $\mathrm{K}_{2} \mathrm{O} . \mathrm{Al}_{2} \mathrm{O}_{3}$ ) was heated:

$12\left(3 \mathrm{CaO} . \mathrm{SiO}_{2}\right)+\mathrm{K}_{2} \mathrm{O} . \mathrm{Al}_{2} \mathrm{O}_{3} \rightarrow \mathrm{K}_{2} \mathrm{O} .23 \mathrm{CaO} .12 \mathrm{SiO}_{2}+3 \mathrm{CaO} \cdot \mathrm{Al}_{2} \mathrm{O}_{3}$ $+10 \mathrm{CaO}$

In mixtures having $3 \mathrm{CaO} \cdot \mathrm{SiO}_{2}: \mathrm{K}_{2} \mathrm{O} \cdot \mathrm{Al}_{2} \mathrm{O}_{3}$ ratios less than $12: 1$, there is an excess of $\mathrm{K}_{2} \mathrm{O} \cdot \mathrm{Al}_{2} \mathrm{O}_{3}$ present, but this may not always be identified in the heated charges because of the relatively small percentage of this compound associated with the reaction products. Thus, in the charge resulting from the heating of a mixture having a 6:1 ratio, the weight of the $\mathrm{K}_{2} \mathrm{O} \cdot \mathrm{Al}_{2} \mathrm{O}_{3}$ calculated to be present is only 6.3 percent of the total. The distribution of this amount of $\mathrm{K}_{2} \mathrm{O} \cdot \mathrm{Al}_{2} \mathrm{O}_{3}$ as interstitial material throughout the specimen would render identification difficult.

\section{RELATIONS OF $2 \mathrm{CaO} . \mathrm{SiO}_{2}$ AND $\mathrm{K}_{2} \mathrm{O} \cdot \mathrm{Al}_{2} \mathrm{O}_{3}$}

Base mixtures of $2 \mathrm{CaO} \cdot \mathrm{SiO}_{2}$ and $\mathrm{K}_{2} \mathrm{O} \cdot \mathrm{Al}_{2} \mathrm{O}_{3}$ within the range of molar ratios of $2 \mathrm{CaO} . \mathrm{SiO}_{2}$ to $\mathrm{K}_{2} \mathrm{O} \cdot \mathrm{Al}_{2} \mathrm{O}_{3}$ of $1: 1$ to $10: 1$, respectively, were prepared and given the same thermal treatment as was given the mixtures of $3 \mathrm{CaO} \cdot \mathrm{SiO}_{2}$ and $\mathrm{K}_{2} \mathrm{O} \cdot \mathrm{Al}_{2} \mathrm{O}_{3}$. Microscopical examinations indicated that the new crystalline phase, found as a product of the reactions between $3 \mathrm{CaO}$. $\mathrm{SiO}_{2}$ and $\mathrm{K}_{2} \mathrm{O} . \mathrm{Al}_{2} \mathrm{O}_{3}$, was formed in the $2 \mathrm{CaO} . \mathrm{SiO}_{2}-\mathrm{K}_{2} \mathrm{O}$.$\mathrm{Al}_{2} \mathrm{O}_{3}$ reactions also. No $3 \mathrm{CaO} \cdot \mathrm{Al}_{2} \mathrm{O}_{3}$ or free $\mathrm{CaO}$ was observed but some $\mathrm{K}_{2} \mathrm{O} \cdot \mathrm{Al}_{2} \mathrm{O}_{3}$ was identified in charges having a low $2 \mathrm{CaO} \cdot \mathrm{SiO}_{2}$ : 
$\mathrm{K}_{2} \mathrm{O} \cdot \mathrm{Al}_{2} \mathrm{O}_{3}$ ratio. As the ratio of $2 \mathrm{CaO} \cdot \mathrm{SiO}_{2}: \mathrm{K}_{2} \mathrm{O} \cdot \mathrm{Al}_{2} \mathrm{O}_{3}$ increased, the amount of new crystalline phase increased until a ratio of about $6: 1$ or $7: 1$ was reached, charges of these ratios appearing to consist largely of the new crystalline product together with an apparently crystalline but unidentifiable material with low refractive index occurring as veinlets. Again assuming that $\mathrm{K}_{2} \mathrm{O} .23 \mathrm{CaO} .12 \mathrm{SiO}_{2}$ is a product of these reactions, it is likely that $\mathrm{CaO} \cdot \mathrm{Al}_{2} \mathrm{O}_{3}$ and some residual $\mathrm{K}_{2} \mathrm{O} . \mathrm{Al}_{2} \mathrm{O}_{3}$ existed in the charges as the thin veins of unidentified material to which reference has been made.

\section{RELATIONS OF $3 \mathrm{CaO} . \mathrm{SiO}_{2}, 2 \mathrm{CaO} . \mathrm{SiO}_{2}, \mathrm{AND} \mathrm{K}_{2} \mathrm{O} . \mathrm{Al}_{2} \mathrm{O}_{3}$}

Since it was found that $\mathrm{CaO}$ and $3 \mathrm{CaO} \cdot \mathrm{Al}_{2} \mathrm{O}_{3}$ were two of the products of reaction of $3 \mathrm{CaO} . \mathrm{SiO}_{2}$ and $\mathrm{K}_{2} \mathrm{O} . \mathrm{Al}_{2} \mathrm{O}_{3}$ and that neither was identified in the reaction products of $2 \mathrm{CaO} . \mathrm{SiO}_{2}$ and $\mathrm{K}_{2} \mathrm{O} \cdot \mathrm{Al}_{2} \mathrm{O}_{3}$, it is reasonable to expect that at some definite proportion of the two calcium silicates and $\mathrm{K}_{2} \mathrm{O} \cdot \mathrm{Al}_{2} \mathrm{O}_{3}$ the amount of $\mathrm{CaO}$ derived from the silicates will be just equal to the amount required by the $\mathrm{Al}_{2} \mathrm{O}_{3}$ to form $3 \mathrm{CaO} \cdot \mathrm{Al}_{2} \mathrm{O}_{3}$. Accordingly, in the preliminary work, various mixtures of the two silicates with $\mathrm{K}_{2} \mathrm{O} \cdot \mathrm{Al}_{2} \mathrm{O}_{3}$ were studied. As a typical case, it was found that a completely crystallized sample, resulting from a mixture corresponding to 2 molecules of $3 \mathrm{CaO} . \mathrm{SiO}_{2}, 4$ molecules of $2 \mathrm{CaO} . \mathrm{SiO}_{2}$, and 1 molecule of $\mathrm{K}_{2} \mathrm{O} \cdot \mathrm{Al}_{2} \mathrm{O}_{3}$, contained the same principal phase observed before, a few grains of $3 \mathrm{CaO} \cdot \mathrm{Al}_{2} \mathrm{O}_{3}$, a small amount of uncombined $\mathrm{CaO}$, and some residual $\mathrm{K}_{2} \mathrm{O} \cdot \mathrm{Al}_{2} \mathrm{O}_{3}$. The exact proportions were not attained, however, until after the discovery of the compound $\mathrm{K}_{2} \mathrm{O} .23 \mathrm{CaO} .12 \mathrm{SiO}_{2}$ in the $2 \mathrm{CaO} . \mathrm{SiO}_{2}-\mathrm{K}_{2} \mathrm{O} . \mathrm{CaO} . \mathrm{SiC}_{2}$ system. A charge consisting of the equivalent of 2 molecules of $3 \mathrm{CaO} . \mathrm{SiO}_{2}, 10$ molecules of $2 \mathrm{CaO} \cdot \mathrm{SiO}_{2}$, and 1 molecule of $\mathrm{K}_{2} \mathrm{O} \cdot \mathrm{Al}_{2} \mathrm{O}_{3}$ was prepared, and after heat treatment, examined by both the powder and polished thinsections methods. It appeared to consist of two phases only, the more abundant phase being the new crystalline compound and the less abundant phase being $3 \mathrm{CaO} \cdot \mathrm{Al}_{2} \mathrm{O}_{3}$. The mean index of refraction of the major phase was about 1.70 and the birefringence about 0.01 . This reaction may be expressed as

$$
\begin{gathered}
2\left(3 \mathrm{CaO} . \mathrm{SiO}_{2}\right)+10\left(2 \mathrm{CaO} . \mathrm{SiO}_{2}\right)+\mathrm{K}_{2} \mathrm{O} \cdot \mathrm{Al}_{2} \mathrm{O}_{3} \rightarrow \mathrm{K}_{2} \mathrm{O} .23 \mathrm{CaO} .12 \mathrm{SiO}_{2}+ \\
\quad 3 \mathrm{CaO} \cdot \mathrm{Al}_{2} \mathrm{O}_{3} .
\end{gathered}
$$

The results of these tests indicate the probable formation of $\mathrm{K}_{2} \mathrm{O} .23 \mathrm{CaO} .12 \mathrm{SiO}_{2}$ in completely crystallized preparations having compositions in the $\mathrm{K}_{2} \mathrm{O}-\mathrm{CaO}-\mathrm{Al}_{2} \mathrm{O}_{3}-\mathrm{SiO}_{2}$ system pertinent to those of portland cement clinker.

\section{RELATIONS OF $3 \mathrm{CaO} . \mathrm{SiO}_{2}, 2 \mathrm{CaO} . \mathrm{SiO}_{2}, \mathrm{~K}_{2} \mathrm{O} . \mathrm{Al}_{2} \mathrm{O}_{3}, \mathrm{AND} \mathrm{Fe}_{2} \mathrm{O}_{3}$}

It has been indicated in this report that the compound $\mathrm{K}_{2} \mathrm{O} .23 \mathrm{Ca}-\mathrm{O}$. $12 \mathrm{SiO}_{2}$ can exist in laboratory clinker containing the oxides $\mathrm{K}_{2} \mathrm{O}$, $\mathrm{CaO}, \mathrm{Al}_{2} \mathrm{O}_{3}$, and $\mathrm{SiO}_{2}$ in amounts likely to be found in portland cement clinker. In addition to these oxides, $\mathrm{Fe}_{2} \mathrm{O}_{3}$ is present in the commercial product. Accordingly an additional mixture was prepared including this other principal oxide, $\mathrm{Fe}_{2} \mathrm{O}_{3}$. This mixture, represented by

$$
3\left(3 \mathrm{CaO} . \mathrm{SiO}_{2}\right)+9\left(2 \mathrm{CaO} . \mathrm{SiO}_{2}\right)+\mathrm{K}_{2} \mathrm{O} \cdot \mathrm{Al}_{2} \mathrm{O}_{3}+\mathrm{Fe}_{2} \mathrm{O}_{3},
$$

was heated to $1,400^{\circ} \mathrm{C}$ and cooled to $1,295^{\circ} \mathrm{C}$ at a rate of $2.5^{\circ} \mathrm{C}$ per minute. The completely crystallized product apparently consisted of only two phases-probably $\mathrm{K}_{2} \mathrm{O} .23 \mathrm{CaO} .12 \mathrm{SiO}_{2}$ and $4 \mathrm{CaO} . \mathrm{Al}_{2} \mathrm{O}_{3} \cdot \mathrm{Fe}_{2} \mathrm{O}_{3}$. 
The maximum and minimum refractive indices, 1.722 and 1.713 , of the potash compound in this charge are considerably higher than those of $\mathrm{K}_{2} \mathrm{O} .23 \mathrm{CaO} .12 \mathrm{SiO}_{2}$ in iron-free charges, possibly because of limited solid solution with an iron compound. Although this increase in indices makes difficult the distinction of the potash compound from $3 \mathrm{CaO} . \mathrm{SiO}_{2}$ and $\beta-2 \mathrm{CaO} . \mathrm{SiO}_{2}$, the maximum index of refraction of the iron-bearing $\mathrm{K}_{2} \mathrm{O} .23 \mathrm{CaO} .12 \mathrm{SiO}_{2}$ is lower than that of $\beta-2 \mathrm{CaO} . \mathrm{SiO}_{2}$ (1.735) and the double refraction (.009) is somewhat higher than that of pure $3 \mathrm{CaO} . \mathrm{SiO}_{2}(.005)$.

Another charge was prepared by adding 25 percent of $4 \mathrm{CaO} \cdot \mathrm{Al}_{2} \mathrm{O}_{3}$.$\mathrm{Fe}_{2} \mathrm{O}_{3}$ to the mixture represented by 2 molecules of $3 \mathrm{CaO} . \mathrm{SiO}_{2}, 10$ molecules of $2 \mathrm{CaO} \cdot \mathrm{SiO}_{2}$, and 1 molecule of $\mathrm{K}_{2} \mathrm{O}_{3} \cdot \mathrm{Al}_{2} \mathrm{O}_{3}$, and the resulting mixture was heated to $1,550^{\circ} \mathrm{C}$ and cooled slowly to $1,260^{\circ} \mathrm{C}$. The product appeared to consist of $\mathrm{K}_{2} \mathrm{O} .23 \mathrm{CaO} .12 \mathrm{SiO}_{2}, 3 \mathrm{CaO} . \mathrm{Al}_{2} \mathrm{O}_{3}$, and $4 \mathrm{CaO} \cdot \mathrm{Al}_{2} \mathrm{O}_{3} \cdot \mathrm{Fe}_{2} \mathrm{O}_{3}$ only. Thus, in these studies, there has been no indication that any compound of potash other than $\mathrm{K}_{2} \mathrm{O} .23 \mathrm{CaO}$.$12 \mathrm{SiO}_{2}$ exists under equilibrium conditions in portland cement clinker insofar as the major oxide constituents are concerned.

These results explain data obtained in a previous unpublished investigation, conducted by the author in 1929. It was observed that greater difficulty was experienced in obtaining complete combination of the $\mathrm{CaO}$ with the other oxide constituents of laboratory clinker mixtures during calcination when $\mathrm{K}_{2} \mathrm{O}$ was substituted for like percentages of $\mathrm{CaO}$, that is to say, the amounts of free $\mathrm{CaO}$ in the clinkers after calcination at a definite temperature for a definite time increased with increasing amounts of substituted $\mathrm{K}_{2} \mathrm{O}$. These results are shown in table 5. The oxide compositions of the raw mixtures calculated to the clinker basis and the oxide compositions of the clinkers assuming a loss of 30 percent of the potash on heating are given. The assumption is based on the amounts of $\mathrm{K}_{2} \mathrm{O}$ which were lost from five representative charges analyzed after heating in the open platinum boats, as also indicated in table 5. The potential compound compositions, considering the $\mathrm{K}_{2} \mathrm{O}$ combined as $\mathrm{K}_{2} \mathrm{O} .23 \mathrm{CaO} .12 \mathrm{SiO}_{2}$, have been calculated and are given in table 5. The reasons for the increased difficulty in obtaining complete combination of the $\mathrm{CaO}$ with the other oxides, as shown by increased amounts of uncombined $\mathrm{CaO}$ remaining in the clinkers, become apparent after a consideration of the changes in the ultimate compositions resulting from the introduction of $\mathrm{K}_{2} \mathrm{O}$. The substitution of $\mathrm{K}_{2} \mathrm{O}$ for $\mathrm{CaO}$ resulted in greatly increased $3 \mathrm{CaO}$.$\mathrm{SiO}_{2}-2 \mathrm{CaO} . \mathrm{SiO}_{2}$ ratios because of the formation of $\mathrm{K}_{2} \mathrm{O} .23 \mathrm{CaO} .12 \mathrm{SiO}_{2}$. In three cases no $2 \mathrm{CaO} . \mathrm{SiO}_{2}$ was present and $\mathrm{CaO}$ was an equilibrium product (Nos. 12, 15, 16). The formation of $2 \mathrm{CaO} . \mathrm{SiO}_{2}$ is very rapid at temperatures of $1,400^{\circ} \mathrm{C}$ and above. Tricalcium silicate, for the most part, results from the reaction $2 \mathrm{CaO} . \mathrm{SiO}_{2}+\mathrm{CaO} \rightarrow 3 \mathrm{CaO} . \mathrm{SiO}_{2}$; but this reaction becomes more and more sluggish as the amount of $2 \mathrm{CaO} . \mathrm{SiO}_{2}$ decreases, and equilibrium is attained with greater difficulty. The existence of the compound $\mathrm{K}_{2} \mathrm{O} .23 \mathrm{CaO} .12 \mathrm{SiO}_{2}$ explains why, for example, the introduction of 2.1 percent of $\mathrm{K}_{2} \mathrm{O}$ into a mixture caused an increase in the amount of uncombined $\mathrm{CaO}$, from 0.1 to 7.9 percent remaining after calcination of $1,525^{\circ} \mathrm{C}$, even though the total $\mathrm{CaO}$ had been decreased from 68.8 to 66.4 percent (Nos. 13 and 16). 
TABLE 5.-Effect of the substitution of $\mathrm{K}_{2} \mathrm{O}$ for $\mathrm{CaO}$ on the combination of $\mathrm{CaO}$ in laboratory cement mixtures

\begin{tabular}{|c|c|c|c|c|c|c|c|c|c|c|c|c|c|c|c|c|c|c|c|c|}
\hline \multirow{2}{*}{ 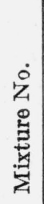 } & \multicolumn{5}{|c|}{$\begin{array}{l}\text { Oxide composition } \\
\text { of raw mixture } \\
\text { (clinker basis) }\end{array}$} & \multicolumn{5}{|c|}{$\begin{array}{l}\text { Oxide composition based on } \\
\text { 30-percent loss of } \mathrm{K}_{2} \mathrm{O} \\
\text { during heating : }\end{array}$} & \multicolumn{6}{|c|}{ Potential $\begin{array}{c}\text { compound com- } \\
\text { position }\end{array}$} & \multicolumn{4}{|c|}{$\begin{array}{l}\text { Uncombined } \mathrm{CaO} \\
\text { after being } \\
\text { heated at- }\end{array}$} \\
\hline & 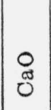 & 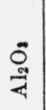 & 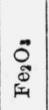 & $\underset{\mathscr{D}}{\stackrel{0}{0}}$ & $\begin{array}{l}0 \\
-1 \\
-1\end{array}$ & ర్లో & $\frac{0_{0}^{\circ}}{4}$ & 兽 & 유 & 윰 & 品 & రి & 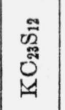 & ర్ల & 皆 & $\begin{array}{l}0 \\
0 \\
0\end{array}$ & $\begin{array}{l}0 \\
0 \\
8 \\
\text { f- } \\
-i\end{array}$ & $\begin{array}{l}0 \\
0 \\
8 \\
\stackrel{9}{4} \\
-7\end{array}$ & $\begin{array}{l}0 \\
0 \\
8 \\
8 \\
0 \\
-1\end{array}$ & $\begin{array}{l}0 \\
0 \\
\text { iี } \\
\text { గ్ } \\
-1\end{array}$ \\
\hline & $\%$ & $\%$ & $\%$ & $\%$ & $\%$ & & & $\%$ & & $\%$ & 10 & & 0 & & $\%$ & $\%$ & $\%$ & $\%$ & o. & $o$ \\
\hline & 66.0 & 11.0 & 0 & 23.0 & 0 & & & 0 & & 0 & 19.5 & & 0 & 2 & 0 & 0 & & 0.7 & 0.0 & 0.0 \\
\hline & O.0.0 & 11. & $\begin{array}{l}0 \\
0\end{array}$ & & 1 & & & 0 & & 7 & & & $\begin{array}{l}15.7 \\
31.3\end{array}$ & & 0 & 0 & & 2 & 1 & $\cdots$ \\
\hline & 63.0 & & 0 & 23.0 & $\overline{3}$ & 63.57 & 1 & 0 & & 2.1 & 13. & 10.6 & 47.0 & 2 & 0 & 0 & $\cdots$ & 5. 3 & 2.8 & 2.6 \\
\hline & 67.0 & 10 & 0 & 23 & 0 & & & 0 & & 0 & & & 0 & & 0 & 0 & 7.7 & 1.8 & 0.3 & 0.0 \\
\hline & & & 0 & & 1 & & & & & & & & & & 0 & & & & 5. & \\
\hline & 65.0 & 10 & 0 & 23 & 2 & 6 & & 0 & 2 & 1.4 & 25 & 16.2 & 31.3 & 2 & 0 & 0 & 7.4 & 5.4 & 4. 5 & 3.1 \\
\hline & 64.0 & & 0 & 23.0 & $\overline{3}$ & 64.58 & 10.09 & 0 & 2 & 2.1 & 23 . & 3.0 & 47.0 & 26.7 & 0 & 0 & 8.0 & 7.5 & 7.0 & 4.3 \\
\hline & 67.0 & & 2. & & 0 & & & & & 0 & 4 & 3 & 0 & & 7. & 0 & 2. & 1.1 & 0.4 & 0.0 \\
\hline & 66.0 & & & & 1 & & & & & 0.7 & & 19 & $|15.7|$ & & 7. & 0 & & 1.6 & 9 & \\
\hline & 65 & & 2.5 & 23 & 2 & & & & & 1.4 & & 6.1 & & & 7. & & & & 3.7 & 3.6 \\
\hline 12 & 64.0 & 7.5 & 2.5 & 23.0 & 3 & 64.58 & 7.5 & 2. 53 & 3. 21 & 2.1 & 27.2 & 0 & 47.0 & 15.7 & 7.7 & 2.4 & 9.7 & 7.3 & 6.9 & 6.8 \\
\hline & 68 & 9.0 & 0 & 22 & 0 & & 9.0 & 0 & 2 & 0 & & 25.5 & 0 & & 0 & 0 & & 3.4 & 2.3 & 0. \\
\hline & & & 0 & & 1 & & & 0 & & 0.7 & & 12.3 & 15.7 & & 0 & & & & & \\
\hline & 66.8 & 9.0 & 0 & & 2 & & 9. & 0 & 2 & & & 0 & 31. & & 0 & & & & 5.4 & 3 . \\
\hline & 65 & & 0 & 22.2 & 3 & 66.40 & 9. & 0 & 22. & 2. 1 & 24 & 0 & 47.0 & 24.1 & 0 & & & 9.8 & 8.4 & 7.9 \\
\hline
\end{tabular}

- Amounts of $\mathrm{K}_{2} \mathrm{O}$ volatilized in 5 representative clinkers are as follows:

\begin{tabular}{|c|c|c|c|c|}
\hline Mix No. & $\begin{array}{c}\text { Original } \\
\mathrm{K}_{2} \mathrm{O}\end{array}$ & \multicolumn{2}{|c|}{$\begin{array}{c}\mathrm{K}_{2} \mathrm{O} \text { in clinker calcined } \\
\text { at indicated tempera- } \\
\text { ture }\end{array}$} & $\begin{array}{c}\text { Percentage } \\
\text { loss of } \mathrm{K}_{2} \mathrm{O}\end{array}$ \\
\cline { 2 - 3 } & $\%$ & $\%$ & $\circ \mathrm{C}$ & $\%$ \\
\cline { 2 - 3 } & 1.0 & 0.75 & $1,450^{\circ}$ & 25 \\
4 & 3.0 & 1.96 & $1,500^{\circ}$ & 35 \\
12.0 & 1.87 & $1,500^{\circ}$ & 38 \\
& 3.0 & 2.15 & $1,500^{\circ}$ & 28 \\
& 2.0 & 1.52 & $1,450^{\circ}$ & 24 \\
\hline
\end{tabular}

As shown in table 5 , the addition of small amounts of $\mathrm{K}_{2} \mathrm{O}$ to clinker mixtures causes marked changes in the relative amounts of the calcium silicates. Thus, for example, 1 percent of $\mathrm{K}_{2} \mathrm{O}$ may react with 21.9 percent of $2 \mathrm{CaO} . \mathrm{SiO}_{2}$ to form 22.3 percent of $\mathrm{K}_{2} \mathrm{O} .23 \mathrm{CaO}$.$12 \mathrm{SiO}_{2}$ with the liberation of 0.6 percent of $\mathrm{CaO}$. This 0.6 percent of $\mathrm{CaO}$ in turn combines with 1.9 percent of additional $2 \mathrm{CaO} . \mathrm{SiO}_{2}$ to form 2.5 percent of $3 \mathrm{CaO} . \mathrm{SiO}_{2}, 23.8$ percent of $2 \mathrm{CaO} . \mathrm{SiO}_{2}$ having been removed from the mixture by the introduction of 1 percent of $\mathrm{K}_{2} \mathrm{O}$. In a mixture in which the potential $2 \mathrm{CaO} \mathrm{SiO}_{2}$ is less than 23.8 percent, the remaining $\mathrm{K}_{2} \mathrm{O}$ reacts with the $3 \mathrm{CaO}^{-} \mathrm{SiO}_{2}$ to form $\mathrm{K}_{2} \mathrm{O} .23 \mathrm{CaO} .12 \mathrm{SiO}_{2}$ and $\mathrm{CaO}$. Under these conditions free $\mathrm{CaO}$ is present as an equilibrium product; 1 percent of $\mathrm{K}_{2} \mathrm{O}$ reacting with 29.1 percent of $3 \mathrm{CaO} . \mathrm{SiO}_{2}$ to liberate 7.7 percent of $\mathrm{CaO}$.

Inspection of the amounts of $\mathrm{K}_{2} \mathrm{O}$ and of free $\mathrm{CaO}$ in certain analyzed commercial clinkers employed in other investigations by this laboratory, however, revealed a few cases in which the determined free $\mathrm{CaO}$ was less than that calculated, assuming all of the $\mathrm{K}_{2} \mathrm{O}$ combined as $\mathrm{K}_{2} \mathrm{O} .23 \mathrm{CaO} \cdot 12 \mathrm{SiO}_{2}$. This has suggested that some of the $\mathrm{K}_{2} \mathrm{O}$ may have reacted with the minor acidic constituents of these clinkers and reduced the amount of potash available for the formation 
of $\mathrm{K}_{2} \mathrm{O} .23 \mathrm{CaO} .12 \mathrm{SiO}_{2}$, the final result being a reduction in the amount of free $\mathrm{CaO}$ in the clinker. For example, if all of the $\mathrm{SO}_{3}$ in a clinker containing 0.2 percent of $\mathrm{SO}_{3}$ reacted with $\mathrm{K}_{2} \mathrm{O}$, the amount of the latter combined as $\mathrm{K}_{2} \mathrm{SO}_{4}$ would be about 0.24 percent. The reaction of this quantity of $\mathrm{K}_{2} \mathrm{O}$ with $\mathrm{SO}_{3}$ rather than with $\mathrm{CaO}$ and $\mathrm{SiO}_{2}$ would decrease the amount of free lime in the clinker by about 1.8 percent.

Additional studies of systems involving potash and minor constituents of clinker are now in progress, and there are indications that such materials may produce marked effects on the constitution of clinker. Evidence that $\mathrm{K}_{2} \mathrm{O} .23 \mathrm{CaO} .12 \mathrm{SiO}_{2}$ reacts with $\mathrm{CaSO}_{4}$ to form $2 \mathrm{CaO} . \mathrm{SiO}_{2}$ and $\mathrm{K}_{2} \mathrm{SO}_{4}$ has been obtained. Recent microscopical examinations of commercial clinkers have revealed the presence of $\mathrm{K}_{2} \mathrm{SO}_{4}$ in many cases.

In this laboratory the compound $\mathrm{K}_{2} \mathrm{O} .23 \mathrm{CaO} .12 \mathrm{SiO}_{2}$ has not as yet been identified definitely in commercial clinkers by means of microscopical examinations. This may have been due to (1) lack of equilibrium during cooling of the clinker resulting in the formation of an unstable compound or of glass containing potash, (2) the reaction of most of the potash present with minor acidic oxides, such as $\mathrm{SO}_{3}$, (3) mistaken identification in powdered specimens due to the similarity in the indices of refraction to those of the calcium silicates, (4) mistaken identification due to the similarity of the etching characteristics of the potash compound with those of one or the other, or both, of the calcium silicates.

\section{SUMMARY}

A portion of the system $2 \mathrm{CaO} \cdot \mathrm{SiO}_{2}-\mathrm{K}_{2} \mathrm{O} \cdot \mathrm{CaO} \cdot \mathrm{SiO}_{2}$ has been investigated by the phase-equilibrium method and the results are presented. A temperature-concentration diagram for the binary system, incomplete because of the temperature limitations of the furnace employed, has been constructed.

One intermediate compound was found in the system, having the composition $\mathrm{K}_{2} \mathrm{O} .23 \mathrm{CaO} .12 \mathrm{SiO}_{2}$. The reported optical properties and the interplanar spacings of the X-ray diffraction pattern were determined on a preparation having the composition closely approaching that of the theoretical for $\mathrm{K}_{2} \mathrm{O} .23 \mathrm{CaO} .12 \mathrm{SiO}_{2}$.

The results of studies on mixtures of $3 \mathrm{CaO} \cdot \mathrm{SiO}_{2}$ and $\mathrm{K}_{2} \mathrm{O} \cdot \mathrm{Al}_{2} \mathrm{O}_{3}$, and of $2 \mathrm{CaO} . \mathrm{SiO}_{2}$ and $\mathrm{K}_{2} \mathrm{O} \cdot \mathrm{Al}_{2} \mathrm{O}_{3}$, indicate that the compound $\mathrm{K}_{2} \mathrm{O} \cdot \mathrm{Al}_{2} \mathrm{O}_{3}$, which previously had been shown to be stable in the $\mathrm{K}_{2} \mathrm{O}-\mathrm{CaO}-\mathrm{Al}_{2} \mathrm{O}_{3}$ and in the $\mathrm{K}_{2} \mathrm{O}-\mathrm{CaO}-\mathrm{Al}_{2} \mathrm{O}_{3}-\mathrm{Fe}_{2} \mathrm{O}_{3}$ systems does not exist in the region of the $\mathrm{K}_{2} \mathrm{O}-\mathrm{CaO}-\mathrm{Al}_{2} \mathrm{O}_{3}-\mathrm{SiO}_{2}$ system, which is directly concerned with portland cement. Possibly these results may be explained by the potash combining with $\mathrm{CaO}$ and $\mathrm{SiO}_{2}$ to form the compound $\mathrm{K}_{2} \mathrm{O}$ $.23 \mathrm{CaO} .12 \mathrm{SiO}_{2}$.

The compound $\mathrm{K}_{2} \mathrm{O} .23 \mathrm{CaO} .12 \mathrm{SiO}_{2}$ was found to exist in a region of the $\mathrm{K}_{2} \mathrm{O}-\mathrm{CaO}-\mathrm{Al}_{2} \mathrm{O}_{3}-\mathrm{SiO}_{2}-\mathrm{Fe}_{2} \mathrm{O}_{3}$ system in which portland cement compositions fall. 
While it is recognized that various minor acidic constituents generally existing in commercial portland cement clinker may combine with all or part of the potash present, evidence was obtained that $\mathrm{K}_{2} \mathrm{O}$ combines as $\mathrm{K}_{2} \mathrm{O} .23 \mathrm{CaO} .12 \mathrm{SiO}_{2}$ in the presence of the major constituents $\mathrm{CaO}, \mathrm{Al}_{2} \mathrm{O}_{3}, \mathrm{SiO}_{2}$, and $\mathrm{Fe}_{2} \mathrm{O}_{3}$, in the proportions occurring in portland cement, and that this ternary compound will occur in clinker limited to those components prepared under equilibrium conditions of heating and cooling.

The author is indebted to G. W. Ward for his assistance and advice in connection with the microscopical studies.

\section{REFERENCES}

[1] L. T. Brownmiller, Am. J. Sci. 29, 260 (1935).

[2] Wm. C. Taylor, J. Research NBS 21, 315 (1938) RP1131.

[3] G. W. Morey, F. C. Kracek and N.L. Bowen, J. Soc. Glass Tech. 14, 149 (1930).

[4] H. F. McMurdie, Private Communication.

[5] W. C. Hansen and R. H. Bogue, Ind. Eng. Chem. 19, 1260 (1927).

[6] L. T. Brownmiller and R. H. Bogue, BS J. Research 3 (1930) RP233; Am. J. Sci. 20, 241 (1930).

Washington, December 30, 1940. 